\title{
VERNACULAR HISTORIOGRAPHY \\ IN MEDIEVAL CZECH LANDS
}

\author{
Marie Bláhová \\ Univerzita Karlova z Praze \\ Marie.Blahova@ff.cuni.cz
}

\begin{abstract}
In this work, it is offered an overview of medieval historiography in the Czech lands from origins to the fifteenth century, both in Latin and in the vernacular languages, as well as the factors that contributed to their development and dissemination.
\end{abstract}

\section{Keywords}

Vernacular Historiography, Czech Chronicles, Medieval Czech Literature.

\section{Resumen}

En este trabajo, se ofrece una visión de conjunto de la historiografía medieval en los terrorios checos desde orígenes hasta el siglo xv, tanto en latín como en las lenguas vernáculas, así como de los factores que contribuyeron a su elaboración y difusión.

\section{Palabras clave}

Historiografía vernácula, Crónicas checas, Literatura checa medieval.

The territory that would become the Czech Lands did not have a tradition of Classical culture. Bohemia and Moravia became acquainted with written culture, one of its integral parts, only after Christianity started to spread to this area in the $9^{\text {th }}$ century. After a brief period in the $9^{\text {th }}$ century when liturgy and culture in Moravia were mainly Slavic, the Czech Lands, much like the rest of Central Europe, came to be dominated by the Latin culture and for several centuries Latin remained the only language of written records.

Alongside the lives of saints and hagiographic legends which helped promote Christianity, ${ }^{\mathrm{I}}$ historical records and later also larger, coherent historical narra-

'Cf. Kubín (20II). 
tives $^{2}$ are among the oldest products of written culture in the Czech Lands. ${ }^{3}$ They were created in the newly established ecclesiastical institutions, such as the episcopal church in Prague and the oldest monasteries. Annals, lists of rulers and Church officials, as well as the first chronicles, were written by educated clerics, although not the highest representatives of the Church as in early medieval Western Europe. ${ }^{4}$ With the possible exception of a list of rulers, which was kept by the court of the Czech Přemyslid dukes and later kings, ${ }^{5}$ these writings were intended for the use of other churchmen. Thanks to their mediation, awareness of at least some stories and events from Czech history as described in the state- and nation-building Chronica Boemorum (Chronicle of the Czechs) ${ }^{6}$ by Cosmas (d. 2I October II25), the first Czech chronicler and dean of the Prague chapter, spread among courtiers, nobles, and gradually even the wider lay public. The nobles heard these stories from their chaplains and other churchmen ${ }^{7}$ who read to them, translating the text at the same time. In this way, the nobility became familiar with notable persons of the history of Bohemia and Moravia and later often commissioned depictions of these heroes and scenes from the past in the churches they built and even in non-sacral buildings. ${ }^{8}$ Paintings and statues, which functioned as a sort of 'popular education', 'then mediated historical information to the secular society from the rulers and highest ranking nobles all the way to the poorest classes.

Prague canons, Cosmas's younger colleagues and followers, then continued to work on the chronicle by adding an annalistic account of the 'history of the

${ }^{2}$ On early historiography in the Czech Lands, see Bláhová (2006b) and Wolverton (2015).

${ }^{3}$ For more on the beginnings of written culture in the Czech Lands, cf. Bláhová (2004b, pp. 53-69; and 2009).

${ }^{4}$ Cf. Guenée (198I, pp. 43-44).

5 Bláhová (1999b).

${ }^{6}$ Cosmae Pragensis Chronica Boemorum (1923), English translation Cosmas of Prague (2008). From the extensive literature on Cosmas and his chronicle, see especially Třeštík (I968) and Wolverton (2015). For more on the notion of 'state- and nation-building chronicle', see Schmale (1985, pp. I26-I27).

7 The spread of literature in secular society is described in Coleman (1997, passim) who uses the example of England and France.

Cf. Bláhová (2002).

${ }^{9}$ Pope Gregory the Great characterised the impact of paintings in his well-known letter to Serenus, Bishop of Marseilles, written around $600 \mathrm{AD}$. 
present' until the $\mathrm{I} 28 \mathrm{Oos},{ }^{\mathrm{IO}}$ while other historical texts were created in monasteries. ${ }^{\text {II }}$

All of these writings were in Latin. The Czech language was finding its way into literature slowly and written evidence of the use of the vernacular is rare. Some Czech glosses appear in Latin and Hebrew texts in the late II ${ }^{\text {th }}$ and early I2 $^{\text {th }}$ century, early reports of Czech war songs and religious hymns in the $12^{\text {th }}$ century, while the first short prayers and basic phrases for religious ceremonies in Czech date to the $\mathrm{I}^{\text {th }}{ }^{\text {ch }}$ century. ${ }^{12}$ The first Czech translations of more extensive religious texts $^{\mathrm{I3}}$ appear a short time later.

In the meantime, the social situation in the Czech Lands was undergoing significant changes. The increasing self-confidence of the nobility, formed in the course of the $\mathrm{II}^{\text {th }}$ and especially the $\mathrm{I}^{\text {th }}$ century, together with its growing political ambitions ${ }^{\mathrm{I} 4}$ and wealth, led in the second half of the $13^{\text {th }}$ century to the establishment of the first representative aristocratic courts which functioned as local centres of court culture. At the same time, the linguistic composition of the population of the Czech Lands was also undergoing a transformation. Foreigners, mostly German clerics and merchants, started settling in Bohemia both individually and in small groups in the $\mathrm{IO}^{\text {th }}$ century. In the $\mathrm{II}^{\text {th }}$ century, they were joined by the wives of some of the rulers who came from German imperial families and brought their own retinues. ${ }^{15}$ While these foreigners arrived in numbers too small to significantly influence the national composition of the local population, their presence helped to generate national self-awareness of the Czech population, especially among intellectuals. The situation significantly changed in the $13^{\text {th }}$ century, when new settlers, mostly from German-speaking parts of Europe, started coming in large numbers in connection with the cultivation of previously unused land, establishment of assarts, the founding of new towns, and mining. ${ }^{16}$ By the late $13^{\text {th }}$ and in the $14{ }^{\text {th }}$ century, German speakers constituted about one third of population of the country. This had a major impact on Czech society and culture. Even the monastic communities of some religious orders

Io Cf. Bláhová (2OIOc and 2OIOd). Older assumptions about the author of First Continuation of Cosmas had been corrected by Reitinger (2015).

II Cf. Bláhová (2006b and 20II).

${ }^{12}$ Cf. Jan Lehár etc. (2008, pp. 55-73); Adamska (2008, p. 77).

${ }^{13}$ Cf. Kyas (I997, pp. 27 and 32) and Vraštil (1926, pp. 334-335).

${ }^{\mathrm{I} 4}$ For more detail, see Bláhová (I995, pp. I2I-223).

Is On the kinship between members of the ruling Czech dynasty and some Imperial families, see Weller (2004).

I6 Berendt (20I2), but also Rady (20I2), Wolverton (20I2), and Žemlička (20I2). 
were German-speaking. ${ }^{17}$ At the same time, however, the Czech rulers had asserted their authority to such an extent that by the late $12{ }^{\text {th }}$ century they were in position to influence developments in the Holy Roman Empire, including the election of new Empire ruler. That the ruler of Bohemia acquired the hereditary rank of King rather than simply Duke can be regarded as visible evidence of the increased international authority of the Czech state. ${ }^{18}$ The country's economic prosperity, which was the result of cultivation of new land and mining of newly discovered silver deposits, further strengthened the international standing of the kings of Bohemia. Consequently, they regularly participated in Imperial politics, maintained contacts with Imperial political leaders, and married their children to the most important Imperial families. The Czech rulers also expanded their influence and asserted their position in neighbouring countries, especially in Austria, Hungary, and Poland. ${ }^{19}$ Under these conditions, they were able to maintain a representative international court, support culture, and engage in extensive and expensive building projects.

In this social climate, vernacular, mainly German, literature started appearing in Bohemia. It did not, however, spread among the German-speaking population in the towns or in the rural border regions, but at the royal court. German was the court's second language - not counting Latin, naturally, which was used mostly by clerics.

In the mid-I230s, German poets whose verses were going out of fashion in the western part of the Holy Roman Empire started coming to the famously generous royal court in Prague in search of livelihood and fame. Their verses spread the reputation of the Czech rulers and promoted their policies. ${ }^{20}$ The upper echelons of the Czech nobility, too, were influenced by German fashions. Their castles (but not their children) $^{2 \mathrm{I}}$ received German names and although their command of the German language was often poor, they admired German culture. ${ }^{22}$ From the late I270s, some leading nobles followed the example of the royal court and also supported German poets who composed for them. ${ }^{23}$ This popularity of German literature at the royal and other aristocratic courts was, however, short-lived

${ }^{17}$ Bok (1992, p. I3).

${ }^{18}$ Cf. Žemlička (2002, pp. 9I-IIO) and Žemlička (2009, pp. 295-3I7).

I9 Žemlička (1986, pp. I7I-I92).

${ }^{20}$ Cf. Behr (1989. pp. 59-212, 234-252), Baumann (1978, pp. 59-6I), Bok (1994, pp. 16-17), Bok and Pokorný (1998).

${ }^{21}$ Bok (1994, p. I3, n. 5).

${ }^{22}$ Cf. Bok (1999, p. I).

${ }^{23}$ Cf. Behr (1989, pp. 213-246) and Bok (1998, pp. I3I-I47). 
and did not last past the end of the $13^{\text {th }}$ century. ${ }^{24}$ In the same period, Czech lyrical poetry, too, flourished at the aristocratic courts. ${ }^{25}$

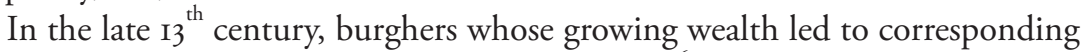
ambitions also started participating in political life. ${ }^{26}$ This process generated various conflicts that reflected both class divisions and national-ethnic tensions. In some cases, rivalries between the mainly German-speaking urban patricians and Czech-speaking nobility even resulted in physical violence, murder plots, and death. $^{27}$

These complex political, economic, and social conditions shaped the ideology of Czech nobility which formed in the second half of the $13^{\text {th }}$ and in early $14^{\text {th }}$ century. The views and attitudes of Czech nobles came to be reflected in the vernacular, now linguistically Czech literature. The new self-confidence of the aristocracy, which came to realise that its authority could be bolstered by appeals to historical traditions and its political intentions aided by historical arguments, led to an increased interest in history. After some tentative attempts in the course of the $13^{\text {th }}$ century, at its end of we see the appearance not only of various Czech epic poems dealing mainly with Classical subjects, legends, and apocrypha, ${ }^{28}$ but also the first historical works written in Czech. The intended recipients of these works were the Czech nobles.

In the late $\mathrm{I}^{\text {th }}$ or early $\mathrm{I} 4^{\text {th }}$ century, the story of Alexander the Great appeared in a Czech version in verse. ${ }^{29}$ Its intended audience was once again the Czech nobility. The unknown author of this work was inspired by Gautier de Châtillon's Alexandreis, sive Gesta Alexandri Magni but probably also knew Ulrich von Etzenbach's German version of the Alexandreis. ${ }^{30}$ The Czech version of the poem, however, clearly reflects the local environment: it contains references to particular events in Bohemia, several Czech names, and Alexander the Great is allegorically identified with the Czech King Přemysl Ottokar II (I253-I278). Unfortunately, only about one third of the text survives and even that in fragments.

${ }^{24}$ Bok (1994, p. I6)

${ }^{25}$ Lehár etc. (2008, pp. 59-6I) and Adamska (2008, p. 77).

${ }^{26}$ Bláhová (1995, pp. 130-132).

${ }_{27}^{27}$ Fiala (1975, pp. 169-170), Šusta (1939, pp. 3-53).

${ }^{28}$ Cf. Antika (1978, pp. 5I-66).

${ }^{29}$ Alexandreida (1963). Cf. Lehár (1983, pp. 77-96), Šváb (1978, pp. 54-58), Alexandreida (1985).

Bok (1994, p. I8). 
Czech translations of other popular works also appeared at this time, for instance a Czech version of the Song of Roland (its text is unfortunately lost), ${ }^{3 \mathrm{I}}$ and the stories of Dietrich of Bern, ${ }^{32}$ while subjects from Jacobus de Voragine's Legenda Aurea (Golden Legend) were retold in Czech verse. ${ }^{33}$ In the late $13^{\text {th }}$ century, the Czech language started appearing in prose works as well, including technical, mainly legal, writings. ${ }^{34}$

In the early I3IOs, after the violent death of Wenceslaus III (I305-I306), the last king of the Přemyslid dynasty, the Czech political elite for the first time in the existence of a Czech state faced the need to elect a ruler. In the end their choice fell on John of Luxembourg, later known as John of Bohemia, a 'foreigner' from a Luxembourg Count family. During this time, when several years of struggle for the throne bolstered the assertiveness of Czech nobles and inflated their political ambitions, an unknown author wrote a new history of Bohemia for them. This second state- and nation-building chronicle in Czech history, known as the Staročeská kronika tak rečeného Dalimila or Dalimilova kronika (Old Czech Chronicle of So-Called Dalimil or Dalimil's Chronicle), ${ }^{35}$ was written in Czech and in order to facilitate its understanding by the mostly illiterate secular audience, it was composed in verses. Of its anonymous author we know only that he was familiar with Latin culture, had a good command of Latin and Czech and some knowledge of Church law. In the chronicle, the author projected the contemporary ambitions and ideology of the Czech nobility onto the 'whole' of Czech history from its mythical origins all the way to hotly contested contemporary struggles, such as conflicts with German patricians in towns and the election of a new ruler to the Czech throne. ${ }^{36}$ The formal aspect of this work shows the strong influence of Latin literature in terms of structure and means of expression, including topoi, exempla, sayings, and etymologies frequently found in Latin works. Also present is direct speech and colourful descriptions of battles. ${ }^{37}$ This chronicle quickly became popular and its author found followers, poets who depicted various mainly contemporary events and added their texts to copies

${ }^{31}$ References to it are found in Dalimil's Chronicle: Staročeská kronika (1988) 52/19, I, 594. Cf. Bok (1994, p. 17) and Bok (1999, p. 2).

${ }^{32}$ Staročeská kronika (1988) 87/42, II, 422. Cf. Pražák (I986), Bok (I999, p. 2).

${ }^{33}$ Bok (1994, p. I8).

${ }^{34}$ Bok (1994, p. 22).

${ }^{35}$ Staročeská kronika (1988); French translation Adde-Vomáčka (2016). Cf. Bláhová (1995) and Bláhová (20Ioe).

${ }^{36}$ Cf. Bláhová (I995, pp. I62-30I).

${ }^{37}$ Cf. Bláhová (1995, pp. 254-27I). 
of Dalimil's Chronicle. ${ }^{38}$ Copying of the chronicle was not to remain limited to the aristocratic environment: in the Late Middle Ages it spread, despite its antiburgher sentiments, among the wealthy urban classes. ${ }^{39}$

In the I340s, Dalimil's Chronicle was translated into Latin and copied in a richly illuminated manuscript for a member of the highest social rank. Some experts believe that this manuscript was intended for Charles of Luxembourg, heir to the Czech throne, who had been brought up largely in France where he lost contact with the Czech language and therefore would not have understood the original Czech version. ${ }^{40}$

Around 1342/1344-1346, Dalimil's Chronicle was translated into Middle High German verses. The translator, a Czech-German cleric living in Prague, possibly one of the knights from the monastery of Knights of the Cross with the Red Star, ${ }^{41}$ produced this translation for his colleagues, German-speaking monks, ${ }^{42}$ mainly members of military monastic orders, probably also Cistercians, but possibly also Prague patricians. ${ }^{43}$ Interestingly, the German translation omits both the patriotic introduction of the Chronicle and the warning against accepting a foreign king which appears in the Czech original at the end of the chronicle. ${ }^{44}$ Likewise, various anti-German formulations present in the Czech text were softened to make the work acceptable to the German-speaking population of the Czech Lands. ${ }^{45}$

The German translation of a brief history of Bohemia which was composed in the early I340s in Latin and known as Excerpta de diversis chronicis (Excerpts from Various Chronicles), was intended for a similar audience. ${ }^{46}$

${ }^{38}$ Cf. Staročeská kronika 2 (1998, pp. 549-599); FRB III, pp. 238-244.

${ }^{39}$ As evidenced mainly by surviving manuscripts. Cf. Staročeská kronika I (I998, pp. 24-44).

${ }^{40}$ Cf. Uhlî́ (2005, p. I53); Bláhová (2016b, pp, 68-69).

${ }^{41}$ This identification of the author is presented in Hilsch (I99I, p. II5). Cf. Vidnamová (2006, p. 59) and with some reservations Brom (2009, pp. 18-19).

${ }^{42}$ Some monasteries in the Czech Lands, mainly cistercian, refused to accept Czech-speaking novices and monks. Cf. Bok (1994, p. I3) and Hledíková (I991, p. I50).

${ }^{43}$ Emler (ed.) (I882a), Brom (ed.) (2009, pp. I02-585). Cf. also Tomsa (I915), Masař́k (I99I), Hilsch (I99I, pp. I03-II5), and Brom (2004); Bláhová (2016b, pp. 69-70)..

${ }^{44}$ Bok (1999, p. 3).

${ }^{45}$ In the $15^{\text {th }}$ century, Dalimil's Chronicle was also translated for Bavarian intellectuals: a modern edition is found in Emler (I882b). For more on this version, which has been largely overlooked, see Masařík (I99I, pp. 5I-52) and MM (2015). There probably existed yet another rhymed translation, of which only a very small fragment survives; see Dunphy (2013, p. 260).

${ }^{46}$ Emler (I884b) and Brom (2009, pp. 84-IOI). See also Hilsch (I99I, pp. I09-III), Brom (2005), and Zouhar (2007); Bláhová (2016b, pp. 70-7I). 
German was not the preferred language at the court of John of Bohemia. The king, who had been educated in France and maintained close relations with the French court, invited various French poets and officials to his court, the most famous of whom was Guillaume de Machault, the king's secretary and court poet. ${ }^{47}$ John's court, however, resided mainly outside Bohemia and had no significant impact on Czech culture. Czech culture was at this time shaped by the Czech nobility and representatives of the Church, the most prominent of whom was John IV of Dražice, Bishop of Prague (I3OI-I343). ${ }^{48}$ Various other legends in verse but also a chivalric epic poem in Czech were composed for an aristocratic audience at this period. ${ }^{49}$

Works of history were at this time still produced by churchmen, which is also why Dalimil's Chronicle did not have a significant impact on the subsequent development of Czech historiography. Original historical writings, such as the Chronicon Aulae Regiae (Zbraslav Chronicle) by Otto of Thüringen and Peter of Zittau, ${ }^{50}$ as well as the first version of the Chronica of Francis of Prague ${ }^{5 \mathrm{I}}$ were created in ecclesiastical circles and still written in Latin.

Significant change came in the reign of John's successor, Charles IV (I346-I378), King of Bohemia, King of the Romans, and from the 1355 Holy Roman Emperor. Charles IV presided over a boom in educational institutions, especially the foundation of a university in Prague in the 1348, which created favourable conditions for the development of academic literature and a broader audience for literature of various kinds. Literature was no longer the exclusive domain of the clergy: it started spreading in secular society, including courtiers, nobles, and eventually even burghers. Despite being educated in Latin, they preferred literature in the vernacular, which is why we see a proliferation of religious and educational literature in Czech at this time. One of the best works produced during this period is a Czech translation of biblical texts, written in the third quarter of the $14^{\text {th }}$ century ${ }^{52}$ and intended as an aid for clergy in their pastoral duties. Various hagiographic legends and mystical treatises in Czech, now already in prose, were written for the laity. ${ }^{53}$ The foundations of Czech technical literature were laid with the compilation of the first Latin-

${ }^{47}$ Bok (I999, p. 5) and Nejedlý (1997).

${ }^{48}$ Hledíková (I99i).

49 Lehár etc. (2008, pp. 63-67)

so Emler (ed.) (I884a). Cf. Bláhová (20ıol).

sI Zachová (ed.) (1997). Cf. Bláhová (20Iof).

52 The first compilation of biblical texts in Czech was created in the third quarter of the $14^{\text {th }}$ century. See Kyas (I98Ia, pp. II-I4; I98Ib, pp. 48-54; 1997, p. 27), Vraštil (I926, p. 335), and Vašica (200I, pp. I49-I50).

${ }^{3}$ Bok (2003, pp. 20-22). 
Czech encyclopaedia at the instigation of Charles IV's: the so-called 'Claret's Dictionary' was created by Master Bartholomaeus de Solencia dictus Claretus (d. 3 May 1370). ${ }^{54}$ At the same time, various Czech translations of popular literature in verse and in prose appeared, ${ }^{55}$ while Czech religious and secular poetry was widespread. ${ }^{56}$

The court of Charles IV also patronised German literature. Various, mainly religious, writings were translated and produced in German for the use of court society. John of Neumarkt (Jan ze Středy; Johannes Noviforensis) (I305/1320I380), Charles's Chancellor and Bishop of Litomyšl and later Olomouc, played an especially prominent role in these efforts. ${ }^{57}$

Of special importance for our purposes, however, is the fact that during the reign of Charles IV we find new trends in historiography. During his seven-year long stay at the French royal court, the future king of Bohemia became aware of the importance of historiography for political ideology as well as practical politics ${ }^{58}$ and took a keen interest in history. He commissioned the writing of historical treatises and even personally tried his hand at it. This led to the creation of official court historiography aimed at defending the ruler's legitimacy, using historical arguments to promote official royal policies, and justifying the political intentions and actions of rulers. ${ }^{59}$ The official historical accounts - such as the Vita Caroli (Autobiography of Charles IV), which includes Charles's own description of his youth and then an anonymous account of his life right up to his election as Roman king in the $1346,{ }^{60}$ Chronica Bohemorum (Chronicle of Bohemia) by Giovanni de Marignolli of Florence (d. 1358/1359), ${ }^{61}$ who at Charles's behest incorporated Czech history into the history of the world, ${ }^{62}$ as well as the Przibiconis de Radenin dicti Pulkavae Chronicon Bohemiae, i.e., the Bohemian Chronicle by Přibík Pulkava of Radenín (d. I378-I380), ${ }^{63}$ which presents Charles's vision of Czech

${ }^{54}$ Cf. zdt (1993) and Bok (1994, p. 22).

"Bok (1994, pp. 23-24).

${ }^{56}$ Bok (1994, p. 23).

${ }^{57}$ Cf. Vaculinova etc. (2016).

${ }^{8}$ Cf. Guenée (198I, pp. 332-347).

59 A definition of court historiography is found in Johanek (I99I, p. 6I). Cf. Bláhová (I999a).

${ }^{60}$ Emler (ed.) (I882d), see also Bláhová (20Iog)

${ }^{61}$ Emler (ed.) (I882c), cf. Bláhová (2010m).

${ }^{62}$ Emler (ed.) (I882c, pp. 492-493).

${ }^{63}$ Emler (ed.) (I893). Cf. Bláhová (20I0y; 1987, pp. 572-580, 590-593; 1999a, pp. 32-39; 2006a, pp. 65-67); Bláhová and Bok (2010). 
history from its mythical origins up to the end of the $1320 \mathrm{~s}^{64}$ - were once again written in the language of medieval scholars, that is, in Latin. Lay readers with an interest in history soon had the option of reading translations, however, and both Vita Caroli and Pulkava's Chronicon Bohemiae were translated into Czech probably during the life of Charles IV. ${ }^{65}$ Pulkava's chronicle, both in the Latin original and in Czech translation, became the most popular and widely disseminated interpretation of Czech state and national history in Late Middle Ages and Early Modern era. In some manuscripts it is immediately followed by Charles's autobiography. The Vita Caroli was later translated several more times and three different medieval translations are currently known. ${ }^{66}$

For the German-speaking populations of territories neighbouring the Lands of the Czech Crown, namely Lusatia and Silesia, both Pulkava's Chronicon Bohemiae and Vita Caroli were translated into German. ${ }^{67}$ In the $15^{\text {th }}$ century, Pulkava's chronicle was again translated into German, this time mainly for the population of German-speaking countries neighbouring Bohemia, with the purpose of describing the historical causes of the Hussite movement. ${ }^{6}$

Other chronicles from the time of reign of Charles IV were also written in Latin, for instance the second version of the Chronicon Pragense by Francis of Prague, chaplain to the Prague Bishop John IV of Dražice and after his death chaplain to the Bishop, later Archbishop, Ernest of Pardubice (I343-I364), the Chronica ecclesiae Pragensis (Chronicle of the Prague Church) by Beneš Krabice of Veitmile, the Summula chronicae tam Romanae quam Bohemicae (Brief Compendium of the Czech and Roman Chronicle) by Neplach, abbot of a Benedictine monastery in the East Bohemian town of Opatovice, and other historical writings. ${ }^{69}$

${ }^{64}$ Cf. Bláhová (1987, pp. 573-575; 1988b, pp. 388-394; 1988a, pp. 269-286; 1999a, pp. 33-38; 2003a, pp. I05-II8; 2012, pp. 236-256).

${ }_{65}$ Emler (ed.) (I882e). Cf. Kyas (1970) and Bláhová (2016a).

${ }^{66}$ Cf. Bláhová (2016b, pp. 7I-76).

${ }^{67}$ These translations cannot be dated with any precision. The German translation of both texts, where Charles's autobiography is attached as a continuation of Pulkava's chronicle, survived in a manuscript which was copied in the second half of the $15^{\text {th }}$ century in Zittau. In the $16^{\text {th }}$ century, the manuscript was acquired by Thomas Rehdiger (I540-1576), a humanist and bibliophile from Wroclaw, with whose library it passed into the possession of the Municipal Library of Wroclaw as sign. $\mathrm{R}$ 304. Since the Second World War, the manuscript has been missing. On German translations of Pulkava's chronicle, see Brom (2010) and Bok (1990).

${ }^{68}$ This translation was made in Bavaria, most likely Nuremberg, probably in the last quarter of the $15^{\text {th }}$ century. Cf. Schneider (I99I, pp. 83-84); Bok (2003).

${ }^{69}$ Cf. Bláhová (1987, pp. 557-648). 
At the court of Charles's successor, Wenceslaus IV (1378-I419), King of Bohemia and until the 1400 King of the Romans, the Latin original and vernacular translations of the official Czech history composed for Charles IV were deemed sufficient for the needs of the royal court and noble society. ${ }^{70}$ The influence of the university and growing numbers of mainly municipal schools contributed to a further spread of education in Czech secular society. Royal courtiers and court officials were particularly interested in both educational literature and reading for pleasure and they preferred books in Czech. Laurentius of Březová (Vavřinec z Březové), courtier of Wenceslaus IV and a university master, ${ }^{71}$ translated for the court several then popular writings, including the Snár či knihy snového vykládanie (Dreambook or Book on the Interpretation of Dreams) and John Mandeville's travel memoirs. At the request of the royal chamberlain John of Eisenberg, Laurentius also started working on a 'Chronicle of the World' in Czech, ${ }^{72}$ which was supplemented by an ecumenical map of the world with Czech captions. This clearly unfinished treatise starts with the creation of the world and ends with the year 678. In the introduction, the author claims that he gathered material for his work from 'Christian, Jewish, and pagan chronicles'. ${ }^{73}$ In fact, he seems to have drawn on a number of well-known medieval compendia, especially Petrus Comestor's Historia scholastica (School History) ${ }^{74}$ and Chronicon pontificum et imperatorum (Chronicle of Popes and Emperors, known also as Chronica Martiniana) by Martin of Opava (in German, von Troppau, also known as Martinus Polonus). ${ }^{75} \mathrm{He}$ supplemented their reports with further sources and added his own interpretation.

Another 'World Chronicle' was composed in the mid-I390s or early $15^{\text {th }}$ century also in Czech by Beneš of Hořovice (d. I422/23), ${ }^{76}$ a member of the lower nobility, a knight in the employ of Wenceslaus $\mathrm{IV}^{77}$ and his supporter in political disputes. Beneš, who undertook a private journey to Spain, possibly to Compos-

${ }^{70}$ Charles IV also commissioned for Wenceslaus a copy of Pulkava's Chronicle, which presented the official history of the Lands of the Bohemian Crown. Cf. Biblioteka Książąt Czartoryskich, cod. I4I4.

${ }^{71}$ Cf. jk (2008); Bláhová (20Ioq).

${ }^{72}$ National Library of the Czech Republic (NK ČR) cod. XVII F 47; unpublished. Cf. Urbánek (1953, p. 7) and Bláhová (1979, p. 309).

${ }_{73}$ Cf. NK ČR XVII F 47, fol. Ir.

${ }^{74}$ Cf. Sherwood-Smith (20IO).

${ }^{75}$ Cf. Brincken (2010).

${ }^{76}$ Cf. V. Bok (200I); Bláhová (2006aa).

77 edláček (I889, p. I83; 1905, p. 139; I924, p. I54). Cf. also Bok (200I). Heck (1980) due to ignorance of relevant sources, believed that Beneš of Hořovice was a fictional character. 
tella, ${ }^{78}$ calls himself in his work 'a Bohemian transmarine knight'. The chronicle starts with the creation of the world, ends with the year 1390, and takes the form of Martiniana. ${ }^{79}$ In the introduction, Beneš states that there are many chronicles that record the lives and deeds of emperors and popes in Latin, but in Czech such writings are but few, which is why he has decided to translate 'some things' from other chronicles into the Czech language. ${ }^{80}$ He based his history of secular rulers on a German translation of the 'history of the world' by the Strasbourg canon Jakob Twinger of Königshofen ${ }^{81}$ and the history of popes on the relevant part of the abovementioned Latin chronicle by the Dominican friar Martin of Opava. ${ }^{82}$ Unlike the world chronicle by Laurentius of Březová, which survives only in autograph, Benešs history enjoyed lasting popularity, as evidenced by the fact that the whole treatise was printed in Prague in the I488, which makes it one of the earliest historical works printed in the Czech language. ${ }^{83}$

With the exception of these treatises, which were written for the education of the courtly and aristocratic society, historiography during the reign of Wenceslaus IV largely stagnated. There are occasional annalistic entries in Latin, which report the ever more unsettled situation in Prague at this time. Also in Latin are reports from the Council of Constance and the trial and burning at stake of Czech religious reformers Master John Hus on 6 July I4I5 and Mater Jerome of Prague on 30 May of the following year, written by Peter of Mladoňovice, ${ }^{84}$ Hus's companion at the Council of Constance.

Impetus for new developments in historiography came with the Hussite revolution, which broke out in the I4I9 in reaction to the execution of Hus. ${ }^{85}$ At this time of widespread unrest, intellectuals and even uneducated soldiers tried to report current events, promote the ideas of their respective sides, and defend their attitudes and actions. Both the Hussite and the Catholic party looked to historical arguments to support their ideology and their policies. The language of Hus-

${ }^{78}$ Badura (1995-I996, pp. 32 and 6I).

79 Cf. von den Brincken (2010, p. I087).

${ }^{80}$ Cf. Knihopis (1925: Nr. 22, pp. 22-23).

${ }^{81}$ Matthews (2010).

${ }^{82}$ The individual parts survive in manuscripts of the Library of the National Museum in Prague II C Io and IV E 29 (History of Emperors) a I E 30 (History of Popes). Cf. Nechutová (2007, pp. IOI-IO2); Bok (2OOI).

${ }_{83}$ Knihopis, Nr. 23, pp. 30-3I.

${ }^{84}$ Petri de Mladoňovic Relatio: pp. 25-I2O, I5O-22I; Petri de Mladoňovic, Narratio: pp. 339350. Cf. Bláhová (20IOv).

${ }^{85}$ For more on the causes and events of the Hussite revolution, see especially Šmahel (2002). 
site and anti-Hussite manifestos, the main instrument of propaganda of the time, was chosen to suit the intended audience, meaning that domestic audience was addressed in Czech, the foreign in Latin or German. ${ }^{86}$ Hussite songs and other propagandistic texts addressed to local population were composed in Czech, but all of the more prominent works of Hussite and Catholic historiography of the times — such as the Origo et diarium belli hussitici (Hussite Chronicle) by Laurentius (Vavřinec of Březová), the Cronica Bartosii de Drahonicz (Chronicle by Bartošek of Drahonice), a historical treatise by Nicolaus Biskupec of Pelhřimov (Nicolaus Pilgramensis), the Chronicon veteris collegiati (Chronicle of the Old Collegiate), ${ }^{87}$ and other writings ${ }^{88}$ - were composed in Latin. ${ }^{89}$ Only Laurentius's Hussite Chronicle was translated into Czech probably in the late $15^{\text {th }}$ century. ${ }^{90}$ The common people were then influenced mainly by visual propaganda, such as paintings, plays, and ritualistic actions. ${ }^{91}$

Use of the vernacular languages, i.e., Czech and German, continued to spread in historiography since the I430s, especially in historical literature coming from the burgher environment and intended for burghers. In the I430s, an unknown Prague burgher and Hussite supporter produced a Czech translation of the Chronicon Treboniense (Chronicle of Třeboň) into Czech - an originally Latin history of Bohemia written in the early I430s by another unknown Prague burgher, a moderate Hussite — supplementing it with further reports and extending it up to the I440. This laid the foundations for a large late medieval compilation of Czech history which came to be known as Staré letopisy české (Old Czech Annals). ${ }^{93}$ In the late I450s, at a time when historians tended to shift their focus to the more distant past, this text was reworked by another Prague burgher, also an Utraquist, who tried to organise his work as a chronicle. He composed an introduction in which he refers to the chronicle of Beneš of Hořovice and states that his work should be viewed as its continuation. He included some personal recollections in the text, giving it a somewhat more subjective form, while temporal

Cf. Bartoš (1932); Molnár (I980)

${ }^{87}$ Cf. Bláhová (20ioj).

${ }^{88}$ Cf. Bláhová (20Ioq; 20Iob; 20Ior).

${ }^{89}$ Cf. Bláhová (1994).

${ }^{\circ}$ Cf. Goll (ed.) (I893: pp. XXXviII-XL); Bláhová (1979, p. 313).

${ }^{91}$ Cf. Fudge (20I4, p. XV).

${ }^{92}$ Höfler (ed.) (1856). Cf. Bláhová (20I0i). The chronicle was published by Höfler (I856, pp. $50-65)$.

${ }_{93}$ Černá etc. (2003); Kaňák and Šimek (1959), Palacký (I829), and Šimek (1937). Cf. also Bláhová (20I0y). The genesis of the Old Czech Annals is described by Čornej (1989) and Kašpar (I980). 
distance from the events he described allowed him to present a more considered assessment. This writer of the Old Czech Annals, did not, however, continue past year I440, which is where his main source and model had also ended.

This chronicle was later added to by further authors and copyists, both Utraquist and Catholic, all firmly rooted in the urban environment and mostly probably municipal scribes. Especially interesting are records for the period of the I435-I448, which bring details of negotiations at the Old Town Hall, changes on the posts of magistrates, councillors, and municipal scribes, but also political events that took place in Prague at this time. This text can be seen as the earliest known example of urban historiography. It is probably the work of one of the university-educated Prague burghers, most likely a member of the municipal office of the Old Town of Prague. The text is thus also an expression of the growing self-confidence of the top echelons of Prague patricians, which is generally evident at this time. ${ }^{94}$

The subsequent parts of Old Czech Annals again follow Czech history, mainly as it appeared from the capital.

In parallel with the Prague redaction of the Old Czech Annals, annalistic records were also created in eastern Bohemia, probably in Hradec Králové. They survive in two versions. They were probably based on the records of municipal scribes of Hradec Králové, which did not survive. ${ }^{95}$ In the last third of the $15^{\text {th }}$ century, these East Bohemian annals were added to the Old Czech Annals.

The text was extended, edited, and subject to ever more additions. Records from the last quarter of the $15^{\text {th }}$ and first decades of the $16^{\text {th }}$ century once again focus on Prague history. They were organised and partly also written by a Prague burgher who displayed a thorough familiarity with the functioning of the municipal council of the New Town of Prague. Records from this time reflect on the one hand the weak rule of Vladislaus II Jagiello (I47I-I5I6; King of Bohemia and since the 1490 King of Hungary), and on the other hand unrest in the town, where social tensions led to repeated rioting directed against both patricians and the Catholic institutions which were trying to use force to suppress Utraquism (I476 and I483). The weak king was unable to efficiently stem the riots and protect his councillors (members of the Old and New Town council were appointed by the king).

94 Cf. Bláhová (2000, pp. 239-24I).

95 Cf. Šủa (I975). 
In the last decade of the $15^{\text {th }}$ century, the 'Prague annals' - which is a fitting description of this part of the Old Czech Annals - focus on disagreements between nobility and urban centres, especially the towns of Prague, regarding the economic and political privileges of towns. The anonymous Prague burgher who was the author of the records of this time, was a keen supporter of burghers' interests and this part of the annals is imbued with anti-aristocratic spirit. Current historical research has analysed the text of the Old Czech Annals up to the year $15399^{96}$

The various parts of the Old Czech Annals differ in their character. Some writers, however much their perspective was limited by their membership of a particular class and residence in a particular town, tried to write a history of Bohemia as a whole, while others focused on the history of one town, reflecting more general developments only to the least extent necessary.

Alongside this extensive work, some briefer vernacular writings which reacted to the current political situation were produced in Prague and elsewhere. We even know that attempts were made at this time to write a new retrospective history of Bohemia.

Officials in both Utraquist and Catholic towns reacted to contemporary events by reporting events in Latin and in both the main vernacular languages used in the Czech Lands. Wenceslas of Jihlava (1398/9-I455/77), a town scribe and wealthy burgher of the Moravian town of Olomouc, wrote in German prose and in Latin several short works which relate events in northern Moravia. ${ }^{97}$ Nicolaus, a town scribe of Znojmo, wrote several anti-Hussite treatises in Latin. ${ }^{98}$ John Lew (Johannes Leonis), a burgher of Most (northwest Bohemia), described in the 1493 in Latin how the town's population mounted a successful defence against a Hussite attack on Palm Sunday I42I. His work was later translated into German. ${ }^{99}$ A description of revolutionary events in Prague in 1483 was probably first written in Latin and later translated into German. ${ }^{\text {I0o }}$ John (d. I4 October I482), son of Ondřej Puklice of Vztuhy, burgermeister of (České) Budějovice (South Bohemia) who was on 25 May 1467 murdered by his political opponents, reported this event in Czech. After John's death, his brother Wenceslas translated

${ }^{96}$ Cf. Zilynskyj (1983 and I984).

${ }^{97}$ Loserth (I880(8I)). Cf. Bláhová (20IOz).

$9^{8}$ Cf. Bláhová (20IOs).

99 Cf. Bláhová (20Ion).

${ }^{100}$ Cf. Bláhová (20Iot). 
the report into Latin. The Czech original was at some point lost and in the second half of the $16^{\text {th }}$ century the report was once again translated into Czech. ${ }^{\text {Ior }}$

Prokop (app. I400-I483), a wealthy burgher and chancellor of the New Town of Prague, was the author of several legal treatises and one theological essay. He also wrote historical works but did not manage to finish any of them. From his 'New Chronicle', which was probably supposed to describe the entire history of Bohemia in verse, only two fragments survive. Similarly, his Zlomky rýmované kroniky české (Fragments of a Czech Chronicle in verse, I419-I420) and Veršované letopisy (Annals in Verse), where Prokop tried to describe in Czech verse the origins of the Hussite movement, also did not progress far past the beginning. In his equally unfinished Latin chronicle written around the 1476, Prokop contrasted the favourable situation in Bohemia during the time of reign of Charles IV with conditions during the Hussite revolution. ${ }^{\mathrm{IO2}}$ Some authors consider Prokop of Prague to have also been author of a Czech poem called 'Král Přemysl Otakar a Záviš̀ (King Přemysl Ottokar and Záviš), ${ }^{103}$ which describes the fate of an ambitious South Bohemian nobleman and royal regent Záviš of Falkenstein (executed the I290).

After Prague and Hradec Králové, another city chronicle was composed in the last third of the $15^{\text {th }}$ century, a German-written Chronik der Stadt Elbogen (Chronicle of the Town of Loket). It describes the town's argument with its feudal lords, the powerful Šlik family, in the I47I-I5O4. ${ }^{104}$ The author, a well-informed burgher of Loket who had personally witnessed the events he described, used the texts of official documents, which he supplemented with his commentary.

In the Late Middle Ages, several chronicles written in the Czech Lands focused on the history of particular noble families and monasteries. These writings, which include chronicles of Franciscan Observants in the Bohemian province by Eberhard Ablauff a Rheno ${ }^{\mathrm{105}}$ and Michael of Carinthia, ${ }^{\mathrm{I} 6}$ Maior chronica Bohemorum moderna and Chronica Ordinis Minorum Observantium by Nicolaus Glassberger (also Nicolaus de Bohemia), ${ }^{107}$ another Franciscan Observant, as well as the chronicle of Beneš the Minorite, which relates the history of Bohemia with

\footnotetext{
Ior Vf. Kováŕ (2007, p. 47).

${ }^{\text {I02 }}$ Cf. Bláhová (2010x), Uhlír (2008).

I03 Jireček (I882).

${ }^{104}$ Schlesinger (I879). Cf. Bláhová (20Iok).

${ }^{\text {Ios }}$ Cf. Bláhová (2OIOa).

${ }^{106}$ Cf. Bláhová (20iopa).

${ }^{107}$ Cf. Seton (1923, pp. I65-17I); Bredenbals (2008).
} 
some emphasis on the Franciscan Order, ${ }^{\mathrm{I} 8}$ or the Chronicon Rosense devoted to the history of the Augustinian monastery in Třeboň (Southern Bohemia) and its founders, the powerful lords of Rožmberk (Rosenberg), ${ }^{109}$ were all written in Latin.

In the turbulent times following the Hussite revolution, especially after the death of Sigismund of Luxemburg in the 1437 and again after the death of Ladislaus the Posthumous in the I45I, the subject of succession to the Czech throne led in Bohemia to heated discussions in which historical arguments were used. It was in these circumstances that a sharply formulated anti-German pamphlet was written, called in the only known surviving manuscript ${ }^{\text {II }}$ Krátkésebranie z českých kronik k výstrazé vérných Čechóv (A Short Collection From Czech Chronicles to Warn Loyal Czechs). ${ }^{\text {III }}$ This short essay is a summary of Czech history from its 'origins' until the 1346. It was written in Czech and based on Dalimil's Chronicle and several other $\mathrm{I}_{4}^{\text {th }}$ century sources. Its author, a moderate Utraquist, uses various examples from history as a warning to the Czechs against choosing another German king.

Also in Czech is the Kronika velmi pěkná o Janu Žižkovi, družiníku krále Vácslava (Very Good Chronicle about Jan Žižka, Member of King Wenceslaus' Retinue), a treatise about the best-known Hussite commander, Jan Žižka of Trocnov (app. 1360-I424). It was produced in eastern Bohemia, most likely in Hradec Králové, probably in the mid- $-5^{\text {th }}$ century. ${ }^{\text {II } 2}$ This document, based mainly on personal recollections of participants, is somewhat unreliable chronicle of the Hussite revolution and mainly emphasises Žižka's military successes.

Another at least brief 'universal chronicle' in Czech was created at the end of the reign of the Czech king Jiří (George) of Poděbrady (I458-I47I). It was part of a larger treatise composed at the request of Jiří of Podébrady by the scholar and encyclopaedist Master Pavel of Prague (known also as Pavel Žídek and in Latin as Paulus or Paulerinus de Praga, or Paulus Judeus; I4I3-I47I). His treatise, called Jiř́ Spravovna ${ }^{\mathrm{II} 3}$ (A Rule Book for George), presented a set of rules according to

${ }^{108}$ Dušek (ed.) (I993). Cf. Dušek (I990) and Bláhová (20Ioga).

${ }^{\text {Iog }}$ Cf. Bláhová (20Ioh).

по Moravský zemský archiv [Moravian Regional Archive], Cerroni’s Collection II, No. Io8.

III Polák (ed.) (1904), Urbánek (ed.) (I958); cf. also Bláhová (20100).

II2 Novotný (ed.) (I923). Results of research of this text are presented in Šůla (I979). Cf. Bláhová (20Iор).

${ }^{\text {II3 }}$ Tobolka (ed.) (I908), see also Bláhová (20I0u). 
which the kingdom ought to be ruled and peace restored. ${ }^{\text {II }}$ The author finished writing this work on II November I47O and published it on I January I47I. The third part of this treatise is historical. After an introduction where Pavel Žídek defines various types of chronicles, a brief universal history is organised in six ages. In the last chapter, which deals with the sixth age, Mater Pavel describes the lives and deeds of prominent personalities of universal history all the way from Caesar to Friedrich III and from Jesus Christ to Pope Paul III.

The Historia Bohemica (History of Bohemia) by Aeneas Silvius Piccolomini was translated into Czech three times. The aim of this historical treatise, written in Latin in the 1458 by the future Pope Pius II, was to describe the origins and consequences of the Hussite heresy and to warn against its spread. ${ }^{\text {II }}$ The work quickly became highly popular in all Latin-reading Europe. It found its readers even in Bohemia and Moravia, both in the Catholic and in Utraquist environment. The first, not very good translation into Czech —or rather, as the translator stated, 'into the language of Moravia' - was completed in the 1487 by Jan Húska, a Catholic clergyman and a canon from Brno. ${ }^{\text {II6 }}$ It was commissioned by two Moravian nobles, brothers Dobeš and Beneš Černohorský of Boskovice and Černá Hora. A new translation of the Historia Bohemica called 'Czech Chronicle' was then published in the I5Io by the Utraquist Mikuláš Konáč of Hodiškov (known also as Finitor). In this translation, Konáč suppressed the anti-Hussite tone of Piccolomini's treatise and focused on describing how the blind Žižka defeated imperial nobles and Emperor and drove them out of Bohemia. The third translation of Piccolomini's Historia Bohemica was completed in the 1585 by Daniel Adam of Veleslavín. This translator did not change the contents or the tone of the work but added an extensive introduction where he explained his critical view of the work. ${ }^{\text {II7 }}$ And finally, in the 1463-I464 Piccolomini's History was translated into German by Wroclaw city scribe Peter Eschenloer, who was commissioned by the municipal council to translate the work for the Germanspeaking population of Silesia. ${ }^{\text {II }}$

II4 'správu královskú i kroniky, skrze které by... se spravoval a královstvie... v pokoj uvedl ['administration of the kingdom as well as chronicles he could use to... administer and bring... peace to the kingdom'] Cf. Tobolka (ed.) (I908, p. I09).

${ }^{\text {IIS }}$ Aeneas Silvius Piccolomini (2005a). Cf. Lamboglia (2010).

${ }^{\text {II6 }}$ Aeneas Silvius Piccolomini (2005c).

${ }^{117}$ Cf. Kopecký (1962, pp. LXXXVII-LXXXIX).

"I8 Aeneas Silvius Piccolomini (2005b). 
The development of written culture, including historiography, in the Czech Lands took a path similar to that of other European countries that were also within the sphere of influence of Latin culture but lacked a Classical tradition, so that the beginnings of written culture were linked to the establishment of Church institutions. Written culture then further evolved with the expansion of a system of education, especially the foundation of universities, but also in connection with developments in secular, mainly royal administration, and the expansion of trade. ${ }^{\text {II }}$

The first historical records and documents of various kinds were created in Bohemia in late IO $^{\text {th }}$ century, almost all in the literary language of medieval Western and Central Europe, that is, in Latin. They were written by clergymen — canons of the episcopal church in Prague, monks of the oldest monastic orders, and in some cases probably by canons of collegiate chapters - for their colleagues. They mediated historical events to the rulers' court and to the political representation of the Czech state.

This situation started changing in the course of the $13^{\text {th }}$ century, when Bohemian nobles gained enough self-confidence to try and assert their political interests. They became aware of the value of historical arguments in law and in practical politics. ${ }^{\mathrm{I} O}$ At the latest by the end of the $13^{\text {th }}$ century, the aristocracy started to show interest in history and to search for historical arguments which could help further their political ambitions. They did not speak Latin and were mostly illiterate, which is why they needed people, mainly clerics, who would mediate historical writings to them. Older treatises written for the clergy did not, however, correspond to the view taken by the nobles of their role in the history of Bohemia, which is why new historical accounts were written for this 'new' aristocratic audience, ${ }^{\text {I2I }}$ chronicles suited to its needs and ambitions. To facilitate understanding, perception, and memorisation, these treatises were written in verse and in Czech. ${ }^{\mathrm{I} 22}$ For instance, the story of Alexander the Great reflected the selfconfidence of the aristocracy and its superiority to other social classes but at the

I19 Cf. Goody (1986) and Genet (1997). For Central Europe, see Adamska (2008).

${ }^{120}$ For more on the importance of historical arguments in propaganda and politics, see Guenée (I98I, pp. 332-350).

${ }_{121}$ Cf. E. Adde-Vomáčka (2016, p. 63).

${ }^{122}$ The earliest vernacular historical writings are in verse in most countries. One of the few exceptions is Island, where one of the oldest historical works, the Hungrvaka, which was written in the first decade of the $13^{\text {th }}$ century, is in Icelandic prose; see Wellendorf (2OII, p. I23). 
same time, it was an allegory of contemporary political situation in Bohemia. ${ }^{\mathrm{I} 3}$ Of crucial importance to the self-confidence and political aims of Czech nobility was Dalimil's Chronicle, a new history of Bohemia which projected the nobles' notions of their social importance onto the entire history of the Czech state. In other words, while in the Přemyslid period historical accounts were written by clerics for clerics, at its end there appeared a new audience - the secular higher nobility to whom books had to be communicated in the vernacular. The first vernacular writings were probably written by clerics or at least persons educated by the Church, but these authors were also familiar with the world of the secular nobility and aware of its needs and demands. Their writings helped to shape the ideology espoused by the nobility.

In the first half of the $14^{\text {th }}$ century, there also appeared another kind of new audience: uneducated members of the knightly orders for whom historical writings were translated into German.

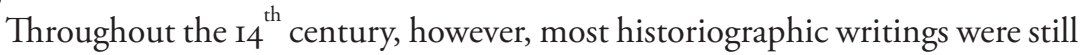
produced in Latin. They were still written by people with Church education, but their audience was changing. Historiography was no longer intended only for the use of clergy but also, and mainly, for the royal court, the political elite, and the educated population of the Czech state, whose numbers grew after the foundation of a university in Prague and whose influence was not limited by a career in the Church. For secular readers, Latin writings produced for the royal court were translated into Czech and in some cases into German.

Latin remained the main language of historical writings in the first third of the $15^{\text {th }}$ century, during the Hussite revolution when cities and towns started to play a prominent role in Czech society and in politics. After the upheavals of the Hussite wars, the situation radically changed. Most historical writings was produced by town officials and wealthy burghers, almost all of them educated laymen who wrote even official records in the national language. At this time, urban historiography appears in the Czech Lands for the first time, i.e., records of events that happened in towns and cities and were of interest to the burghers. Almost all of these writings were produced in the vernacular and focused on the 'history of the present'. The most important historical treatise of this time is the Staré letopisy české (Old Czech Annals), which appeared in Czech and in various versions, written mostly in the towns of Prague but also outside the political centre, in eastern Bohemia.

${ }^{123}$ Lehár (1993, pp. 77-96). 
Reports of contemporary events in towns were written mostly in vernacular, i.e., in Czech or in German, depending on the intended audience. Latin was used for this purpose only within the Church environment.

The first town chronicle in German, the Chronik der Stadt Elbogen, was written in Bohemia before the end of the $15^{\text {th }}$ century. Like many similar chronicles in other countries, it chiefly concerned disputes between a town and its feudal lords.

Czech medieval historians, like their West European colleagues, chose not only the subject of their chronicle, but also the style of narration and means of expression $^{\text {I24 }}$ mainly with a view to suiting their intended audience. Some authors wrote for intellectuals, people with some education and a degree of familiarity with literary language, while others wrote for laymen who were illiterate and did not understand Latin. Works intended for a secular audience, be it the court society, nobility, or burghers, were not only written in the vernacular languages ${ }^{\mathrm{I} 25}$ but also in verse, which helped the audience to absorb and remember the content. Here, verses were not seen as 'unreliable' or 'untrue' as in some cases in Western Europe. ${ }^{\mathrm{I} 6}$

With the further spread of education including knowledge of Latin, interest in vernacular texts, including historiography, did not diminish. Although verses were no longer needed for ease of recall, secular nobles and especially the burghers despite their education continued to prefer historical writings in the vernacular.

UNPUBLISHED SOURCES

Biblioteka Książąt Czartoryskich, cod. I4I4.

Knihovna Národního muzea IV E 29.

Knihovna Národního muzea I E 30.

Knihovna Národního muzea II C io.

${ }^{124}$ For more detail, see Bláhová (1995, pp. 34-55).

${ }^{125}$ For the origins of linguistically national literatures, cf. especially Curtius (I965, p. 387), Spunar (1972, pp. I6I-180), Ineichen etc. (1964, p. I87), and Langosch (1990: passim). For more on historical writings produced in national languages, see Herkommer (1972), Tyson (1979), Bláhová (I995, pp. 4I-55), Damian-Grynt (I999, pp. I72-I73), and Wellendorf (20II, pp. III-I42).

${ }_{126}$ One of the Flemish translators of Pseudo-Turpin's versed chronicle expressed it simply as follows 'nus contes rimés n'est verais' ('while its translation in prose should be truthful'). Cf. Tyson (1979, pp. 186-187). 
Moravský zemský archiv, Cerroniho sbírka II, č. Io8.

Národní knihovna České republiky, cod. XVII F 47.

EDITED SOURCES

Aeneae Silvii, 1988: Historia Bohemica (ed. D. Martinková, A. Hadravová, J. Mátl, Fr. Šmahel, Praha.

Aeneas Silvius Piccolomini, 2005a: Historia Bohemica. Bd. I, Historich-kritische Ausgabe des lateinisch Textes (hrsg. von J. Hejnic, H. Rothe; besorgt von J. Hehnic mit einer deutschen Übersetzung von E. Udolph), Köln-WeimarWien.

Aeneas Silvius Piccolomini, 2005b: Historia Bohemica. Bd. 2, Die frühneuhochdeutsche Übersetzung (I463) des Breslauer Stadtschreibers Peter Eschenloër (hrsg. von J. Hejnic, H. Rothe, V. Bok), Köln-Weimar-Wien.

Aeneas Silvius Piccolomini, 2005c: Historia Bohemica, Bd.3, Die erste alttschechische Übersetzung (I487) des katholischen Priesters Jan Hüska (hrsg. von J. Hejnic, H. Rothe, J. Kolár), Köln-Weimar-Wien.

Alexandreida, 1963: Alexandreida (ed. V. Vážný, úvod Fr. Svejkovský), Praha.

Brom, V. (ed.), 2009: Di tutsch kronik von Behem lant. Die gereimte deutsche Übersetzung der Alttschechischen Dalimil-Chronik = rýmovaný nèmecký preklad staročeské Dalimilovy kroniky, Brno.

Cosmae Pragensis (1955)', Chronica Boemorum (ed. B. Bretholz unter Mitarbeit von W. Weinberger), Berlin.

Černá, A. M., Čornej, P., Klosova, M., 2003: Staré letopisy české (Texty nejstarší vrstvy), Praha.

Dušek, L. (ed.), 1993: "Benedicti minoritae dicti Chronica et eius continuatio", in Zakony Franciszkańskie w Polsce (red. J. Kłoczowski) [Tom I, Franciszkanie w Polsce średniowiecznej, część 2 i 3, Franciszkanie na ziemiach polskich], Kraków, pp. 323-434.

Emler, J., (ed.), I882a: Di tutsch kronik von Behem lant wirt zcu rim wol bekant [Fontes rerum Bohemicarum III], Praha, pp. 257-297.

_ (ed.), I882b: Die pehemische Cronica dewcz [Fontes rerum Bohemicarum III], Praha, pp. 257-297.

- (ed.), I882c: Kronika Jana z Marignoly [Fontes rerum Bohemicarum III], Praha, pp. 492-604.

— (ed.), I882d: Život císaře Karla IV. /Vita Karoli IV. imperatoris [Fontes rerum Bohemicarum III], Praha, pp. 323-368. 
— (ed.), i882e: Život císaře Karla IV [Fontes rerum Bohemicarum III], Praha, pp. 369-395.

— (ed.), I884a: Petra Žitavského Kronika zbraslavská [Fontes rerum Bohemicarum IV], Praha, pp. I-337.

_ (ed.), I884b: Veršované letopisy [Fontes rerum Bohemicarum IV], Praha, pp. 23I-237.

- (ed.), I893: Kronika Pulkavova, [Fontes rerum Bohemicarum V], Praha pp. I-326.

František, Š. (ed.), 1937: Staré letopisy české z vratislavského rukopisu, Praha.

Goll, J. (ed.), I893: Vavrince z Březové Kronika husitská [Fontes rerum Bohemicarum V], Praha, pp, 327-534.

Höfler, K. (ed.), I856: "Chronicon Treboniense", in Geschichtsschreiber der hussitischen Bewegung in Böhmen, Hist. Kommission (= Fontes rerum Austriacarum, I. Scriptores, II,I), Wien, pp. 50-65.

Jireček, J. (ed.), I882: Král Přemysl Otakar a Záviše [Fontes rerum Bohemicarum III], Praha, pp. 240-242.

Kaňák, M., František, Š. (ed), 1959: Staré letopisy české z rukopisu križovnického, Praha. Knihopis, I925: Knihopis československých tisků od doby nejstarši až do konce XVIII. století. Dil I. Prvotisk (do r. I50o), Praha.

Loserth, J., I880/8I: "Historische Aufzeichnungen aus der Hussitenzeit des Stadtschreibers Wenzel von Iglau", Mitteilungen des Vereins für die Geschichte der Deutschen und Böhmen, I9, pp. 8I-89.

Palacký, F. (ed.), I829: „Staří letopisové čeští od roku 1378 do 1527 čili pokračování v kronikách Přibíka Pulkavy a Beneše z Hořovic z rukopisů starých vydané“, Praha Scriptorum rerum bohemicarum. Tomus III, Annales patrio sermone scripti, vulgo Pulkavae et Benessii de Hořowic chronicorum continuatore anonymi W Praze: Péčj a nákladem král. české Společnosti Nauk, I829; Dílo Františka Palackého. Svazek druhý, [Staří letopisové čeští od roku 1378 do 1527 čili pokračování v kronikách Přibíka Pulkavy a Beneše z Hořovic z rukopisů starých vydané / vybral a uspořádal Jaroslav Charvát ; slovníčkem opatřil František Krčma], Praha.

Petri de Mladoňovic, 1932a: Relatio de Magistro Johanne Hus (ed. V. Novotný) [Fontes rerum Bohemicarum VIII], Praha, pp. 25-I20, I50-22.I.

- 1932 b: Narratio de Magistro Hieronymo Pragensi, pro Christi nomine Constantie exusto, (ed. V. Novotný) [Fontes rerum Bohemicarum VIII], Praha, pp. 339-350.

Polák, A. (ed.), 1904: Krátké sebránie z českých kronik k výstraze věrných Čechóv, Praha. 
Seton, W., 1923: Nicholas Glassberger and his Works. With the Text of his Maior Cronica Boemorum Moderna (A.D. I200 - I3I0), Manchester.

Schlesinger, L. (ed.), 1879: Die Chronik der Stadt Elbogen (I47I-I504), Prag.

Staročeská kronika, 1988: Staročeská kronika tak réčeného Dalimila (ed. J. Daňhelka, K. Hádek, B. Havránek, N. Kvítková), 2 vols, Praha.

Tobolka, Z. V. (ed.), I908: M. Pavla Židka Spravovna, Praha.

Urbánek Rudolf (ed.) (1958), O volbě Jiřriho z Poděbrad za krále českého 2. března I458, ČSAV, Praha, pp. 29-4I

Zachová, J. (ed.), 1997: Kronika Františka Pražského [Fontes rerum Bohemicarum. Series nova, tomus I], Praha.

Novotný, V. (ed.), I923: Kronika velmi pěkná o Janu Žižkovi, čeledinu krále Václava, Praha.

\section{LITERATURE}

Adamska, A., 2008: "Orality and Literacy in Medieval East Central Europe“, in E. Mundal, J. Wellendorf, J. (eds.), Oral Art Forms and their Passage into Writing, Kopenhagen, pp. 69-83.

Adde-Vomáčka, E., 2016: La chronique de Dalimil, Les débuts de l'historiographie nationale tchèque en langue vulgaire au XIV siècle, Paris.

Antika a česká kultura, 1978: Antika a česká kultura, Praha.

Bad’ura, B., 1995-1996: "Styky mezi českým královstvím a Španělskem ve středověku“, Táborský archiv, 7, pp. 5-87.

Bartoš, Fr. M., 1932: Manifesty mèsta Prahy z doby husitské, Praha.

Baumann Winfried (1978), Die Literatur des Mittelalters in Böhmen (deutschlateinisch-tschechische Literatur vom Io. bis zum Is. Jahrhundert), Oldenburg, München

Behr, H.-J., 1989: Literatur als Machtlegitimation. Studien zur Funktion der deutschsprachigen Dichtung am böhmischen Königshof im I3. Jahrhundert, (= Forschungen zur Geschichte der älteren deutschen Literatur, Bd. 9), München.

Berendt, N. (ed.), 20I2: The Expansion of Central Europe in the Middle Ages, Farnham-Ashgate.

Bláhová, M., I979: "Vavřinec z Březové a jeho dílo", in Vavřinec z Březové, Husitská kronika. Píseň o vitězství u Domažlic (přel. F. Heřmanský a J. B. Čapek, úvod M. Bláhová), Praha pp. 305-316, 380-389.

—_, 1987: "Kroniky doby Karla IV“, in Kroniky doby Karla IV (ed. M. Bláhová, transl. J. Pavel, M. Bláhová, J. Zachová), Praha, pp. 557-594. 
—_, 1988a: "Odraz státní ideologie v oficiální historiografii doby předhusitské", Folia historica Bohemica, I2, pp. 269-286.

_ Zeit Karls IV“, Fälschungen im Mittelalter, MGH, Schriften 33/I, pp. 388394.

—_, 1994: "Česká historiografie v husitské revoluci", in Husitstvi - reformace renesance, Sbornik k šedesátinám Františka Šmahela (red. J. Pánek, M. Polívka, N. Rejchrtová) vol. 2, Praha, pp. 439-448.

_-, I995: Staročeská kronika tak réčeného Dalimila v kontextu středověké historiografie latinského kulturního okruhu a jeji pramenná hodnota; Historický komentár; Rejstř́k, (=Staročeská kronika tak rééeného Dalimila 3), Praha.

—, I999a: "Offizielle Geschichtsschreibung in der mittelalterlichen böhmischen Ländern", in Die Geschichtsschreibung in Mitteleuropa. (= Subsidia historiographica I), Toruń, pp. 2I-40.

—_ I I999b: "Středověké katalogy českých knížat a králů a jejich pramenná hodnota", Średniowiecze polskie i powszechne, I, pp. 33-63.

__ 2000: "Stadt, Bürgertum und Städtewesen im Spiegel der Geschichtsschreibung", in Städtische Geschichtsschreibung im Spätmittelalter und in der frühen Neuzeit (hrsg. v. P. Johanek), Köln - Weimar - Wien, pp. 233246.

—_, 2002: "Obrazové dějiny v českých zemích ve středověku", Imago narrat. Obrazjako komunikat w społeczeństwach europejskich (red. S. Rosik, P. Wiszewski), Wrocław, pp. 217-249.

__ 2003a: “...ad probos mores exemplis delectabilibus provocemus... Funkce oficiální historiografie v představách Karla I“, in Ad vitam et honorem. Profesoru Jaroslavu Mezníkovi prátelé a žáci k pétasedmdesátým narozeninám ( $\mathrm{k}$ vydání připravili T. Borovský, L. Jan a M. Wihoda), Brno, pp. Io5-II8.

— , 2003b: "Historická pamět v pramenech raně přemyslovských Čech", in Dějiny ve věku nejistot. Sbornik $k$ príležitosti 7o. narozenin Dušana Třštika (uspoř. J. Klápště, E. Plešková, J. Žemlička), Praha, pp. 53-69.

__ 2006a: "Die Hofgeschichtsschreibung am böhmischen Herrscherhof im Mittelalter", in: R. Schieffer, J. Wenta (eds.), Die Hofgeschichtsschreibung im mittelalterlichen Europa, Toruń pp. 5I-73.

__, 2006aa: "Beneš z Hořovic", in Biografický slovník českých zemí, 4, Praha p. 400.

— 2006b: "Dějepisectví v českých zemích přemyslovského obdobi", in Przemyślidzi i Piastowie - twórcy i gospodarze średniowiecznych monarchii (red. J. Dobosz), Poznań, pp. I07-I39. 
—_, 2009: "Písemná kultura přemyslovských Čech", in P. Sommer, D. Třeštík, J. Žemlička (eds.), Premyslovci. Budováni českého státu, Praha, pp. 508-529, 640-645.

— , 20I0a: "Ablauff a Rheno, Eberhard", in G. Dunphy (ed.), Encyclopedia of the Medieval Chronicle, Leiden-Boston, pp. 3-4.

- 20Iob: "Bartholomaeus of Drahonice", in G. Dunphy (ed.), Encyclopedia of the Medieval Chronicle, Leiden-Boston, p. I44.

- 20Ioc: "Continuatio Cosmae I", in G. Dunphy (ed.), Encyclopedia of the Medieval Chronicle, Leiden-Boston, pp. 489-490.

—, 2orod: "Continuatio Cosmae II", in G. Dunphy (ed.), Encyclopedia of the Medieval Chronicle, Leiden-Boston, pp. 490-49I.

—, 20Ioe: "Dalimil", in G. Dunphy (ed.), Encyclopedia of the Medieval Chronicle, Leiden-Boston, pp. 504-505.

—, 20Iof: "Francis of Prague", in G. Dunphy (ed.), Encyclopedia of the Medieval Chronicle, Leiden-Boston, pp. 832-633.

—, 20Iog: "Charles IV", in G. Dunphy (ed.), Encyclopedia of the Medieval Chronicle, Leiden-Boston, pp. 266-267.

_ - 2oroga: "Chronicle of the so-called Beneš the Minorite", in G. Dunphy (ed.), Encyclopedia of the Medieval Chronicle, Leiden-Boston, p. 306.

— , 20Ioh: "Chronicon Rosense", in G. Dunphy (ed.), Encyclopedia of the Medieval Chronicle, Leiden-Boston, p. 4I2.

—, 20Ioi: "Chronicon Treboniense", in G. Dunphy (ed.), Encyclopedia of the Medieval Chronicle, Leiden-Boston, p. 438.

—, 20Iоj: "Chronicon veteris collegiati“, in G. Dunphy (ed.), Encyclopedia of the Medieval Chronicle, Leiden-Boston, p. 444.

—, 2orok: "Chronik der Stadt Elbogen", in G. Dunphy (ed.), Encyclopedia of the Medieval Chronicle, Leiden-Boston, pp. 430-43I.

—, 20Iol: "Chronicon Aulae Regiar", in G. Dunphy (ed.), Encyclopedia of the Medieval Chronicle, Leiden-Boston, pp. 30I-302.

—, 20I0m: "John of Marignolli", in G. Dunphy (ed.), Encyclopedia of the Medieval Chronicle, Leiden-Boston, pp. 934-935.

—, 20Ion: "Johannes Leonis", in G. Dunphy (ed.), Encyclopedia of the Medieval Chronicle, Leiden-Boston, pp. 924-925.

__ , 20I00: "Krátké sebranie z českých kronik k výstrazě věrných Čechóv", in G. Dunphy (ed.), Encyclopedia of the Medieval Chronicle, Leiden-Boston, p. 980.

—_, 20Iop: "Kronika velmi pěkná o Janu Žižkovi, družiníku krále Václava IV“, in G. Dunphy (ed.), Encyclopedia of the Medieval Chronicle, Leiden-Boston, pp. 982-983. 
—, 2oropa: "Michael of Carinthia", in G. Dunphy (ed.), Encyclopedia of the Medieval Chronicle, Leiden-Boston, pp. IIo9-IIIo.

—, 2oroq: "Laurentius of Březová", in G. Dunphy (ed.), Encyclopedia of the Medieval Chronicle, Leiden-Boston, pp. Iooo-IooI.

—, 20Ior: "Nicolaus Biskupec of Pelhřimov", in G. Dunphy (ed.), Encyclopedia of the Medieval Chronicle, Leiden-Boston, p. II44.

- 2 20Ios: "Nicolaus of Znojmo", in G. Dunphy (ed.), Encyclopedia of the Medieval Chronicle, Leiden-Boston, p. II47.

—, 20Iot: "Passio Pragensium", in G. Dunphy (ed.), Encyclopedia of the Medieval Chronicle, Leiden-Boston, pp. II88-II89.

— , 20Iou: "Paulus de Praga", in G. Dunphy (ed.), Encyclopedia of the Medieval Chronicle, Leiden-Boston p. II94.

- 20Iov: "Peter of Mladoňovice“, in G. Dunphy (ed.), Encyclopedia of the Medieval Chronicle, Leiden-Boston, pp. I204-I205.

—, 20Iox: "Prokop of Prague", in G. Dunphy (ed.), Encyclopedia of the Medieval Chronicle, Leiden-Boston, p. 1237.

—_, 20Ioy: "Staré letopisy české", in G. Dunphy (ed.), Encyclopedia of the Medieval Chronicle, Leiden-Boston, pp. I386-I387.

—, 20IOz: "Wenceslas of Jihlava", in G. Dunphy (ed.), Encyclopedia of the Medieval Chronicle, Leiden-Boston, pp. I498-I499.

— , 20Ir: "Böhmens Spannungsverhältnis zum Reich im Spiegel der böhmischen Historiographie der Přemyslidenzeit“, in Böhmen und seine Nachbarn in der Přmyslidenzeit (hrsg. von I. Hlaváček und A. Patschowski), Ostfildern, pp. 34I-384.

—_, 20I2: "Představy o společném původu Čechů a Poláků ve stř̌edověké historiografii“", Historia Slavorum Occidentis. Czasopismo historyczne (Časopis historicky), 2/3, pp. 236-256.

—, 20ı6a: "Soudobé kroniky o Karlovi IV“, in M. Bláhová, Z. Lukšová, M. Nodl, Karel IV. v soudobých kronikách, Praha, pp. 3I-64 [fortcomming]

—_, 20I6b: "Překlady "českých dějin" z doby vlády prvních Lucemburků do národních jazyků, Cesta k rozmanitosti aneb Kavárenský povaleč digitálnim historikem stredověku, pp. 65-78 [forthcoming].

Bláhová M., Bok, V., 20Io: "Pulkava of Radenín, Přibík“, in G. Dunphy (ed.), Encyclopedia of the Medieval Chronicle, Leiden-Boston. pp. I246-I247.

Bok, V., I990: "Wolfenbüttelský fragment německého překladu Pulkavovy kroniky", Listy filologické, II3, pp. 24-31.

— - 1994: "Zur literarischen Situation im Böhmen des I4. Jahrhunderts", Wolframstudien XIII, Literatur im Umklreis des Prager Hofs der Luxemburger, 
Schweinfurter Kolloquium 1992 (ed. J. Heinzle, L. P. Johnson, G. VollmannProfe), Berlin, pp. IO-27.

— I998: "Středohornoněmecká poezie na dvorech české šlechty", in V. Bok, J. Pokorný (eds.), Moravo, Čechy, radujte se! (Němečtí a rakouští básníci v českých zemch za poslednich Premyslovcui), Praha , pp. I3I-I47.

—_, 1999: "Deutsche Literatur in Böhmen in der Zeit der Herrschaft Johanns von Luxemburg", in Fata Libellorum. Festschrift für Franzjosef Pensel zum 70. Geburtstag (hrsg. von R. Bentzinger und U. D. Oppitz), Göppingen, pp. IIO.

—_, 200I: "Zur Rezeption der Weltchronik Jakob Twingers von Königshofen in Böhmen“, in Deutsche Literatur des Mittelalters in Böhmen und über Böhmen. Vorträge der internationalen Tagung, veranstaltet vom Institut für Germanistik der Pädagogischen Fakultät der südböhmischen Universität České Budějovice (hg. v. D. Flieger und V. Bok), České Budějovice-Wien, pp. 269-284.

—, 2003: "Pulkava, Přibík, von Radenín", in Deutsche Literatur des Mittelalters. Verfasserlexikon, Bd. II, Berlin, col. I284.

Bok, V., Pokorný, J.(eds.), 1998: Moravo, Čechy, radujte se! (Němečtí a rakouští básnici v českých zemich za poslednich Premyslovcui), Praha.

Bredenbals, J., 2008: “Funktion, Form und Themen der „Chronica fratris Nicolai Glassberger ordinis Minorum Observantium“, Wissenschaft und Weisheit franziskanische Studien zur Theologie, Philosophie und Geschichte, 7I, pp. II5-I42.

Brincken, A. D., von den, 20I0: "Martin of Opava", in G. Dunphy (ed.), Encyclopedia of the Medieval Chronicle, Leiden-Boston, pp. I085-I088.

Brom, V., 2004: "Zu einigen historisch-semantischen Spezifika des Spätmittelhochdeutschen in den böhmischen Ländern. Am Beispiel der gereimten deutschen Übersetzung der Alttschechsichen Reimchronik des sogenannten Dalimil“, Sbornik praci filozofické fakulty brnènské univerzity $R$, 9, pp. 199235 .

—_, 2005: "Der sog. „Abriss“ und sein Verhältnis zur deutschen Reimübersetzung der Dalimil-Chronik“, Sborník prací filozofické fakulty brnènské univerzity $R$, I0, pp. I37-I49.

_ _ 20I0: "Aus der offiziellen böhmischen Historiographie Karls IV. Die Pulkava-Chronik in drei Sprachversionen“, Brünner Beiträge zur Germanistik und Nordistik, I5/I-2, pp. 5-I9.

CF, JK, 2008: "Vavřinec z Březové", in Lexikon české literatury 4/II, U-Ž, Praha, pp. I266-I268.

Clanchy, M. T., 20I2: From Memory to Written Record. England, 1066-1307, Oxford - Cambridge. 
Coleman, J., 1997: Public Reading and the Reading Public in Late Medieval England and France, Cambridge.

Curtius, E. R., 1965: Europäische Literatur und lateinisches Mittelalter, BernMünchen.

Černý, J., Kouba, J., Lébl V., Ludvová J., Pilková Z., Sehnal, J., Vít, P., I983: Hudba v českých dějinách, Praha.

Čotnej, P., 1989: "Staré letopisy české ve vývoji české pozdně středověké historiografie", in Problémy dějin historiografie IV, AUC, phil. et hist. I, Praha, pp. 33-59.

Damian-Grynt, P., 1999: The New Historians of the Twelfth-Century Renaissance. Inventing Vernacular Authority, Woodbridge.

Dunphy, G. (ed.), 2010: Encyclopedia of the Medieval Chronicle, 2 vols, LeidenBoston.

—_, 2013: "Merborts Chronicon: Eine mittelhochdeutsche Dalimilübersetzung bei Martin Opitz", Euphorion, Zeitschrift für Literaturgeschichte, I07/3, pp. 259-268.

Dušek, L., I990: "Kronika tzv. Beneše Minority a její pokračování", Minulostí Západočeského kraje, 26, pp. 7-II2.

Fiala, Z., 1975²: Premyslovské Čechy. Český stát a společnost v letech 995-1310, Praha. Fudge, Th. A., 20r4: "Visual Heresy and the Communication of Ideas in the Hussite Reformation", in Th. A. Fudge, Heresy and Hussites in Late Medievale Europe, Ashgate.

Genet, J.-Ph., 1997: "Histoire et système de communication au Moyen Âge“, in G. Ph. Genet (ed.), L 'histoire et les nouveaux publics dans l'Europe médiévale (XIII $-X^{e}$ siècles). Actes du colloque organisé à la Casa de Velazques, I993, Paris, pp. II-30.

Goody, J., 1986: La logique de l'écriture. Aux origines des sociétés humaines, Paris. Guenée, B., I981: Histoire et culture historique dans l'Occident médiéval, Paris.

Heck, R., 1980: "Czasy Karola IV we wrocławskim rękopise Starych Latopisów Czeskich“, Sbornik prací fllozofické fakulty Brnènské univerzity C, 27, pp. 43$8 \mathrm{I}$.

Herkommer, H., 1972: Überlieferungsgeschichte der "Sächsischen Weltchronik". Ein Beitrag zur deutschen Geschichtsschreibung des Mittelalters, München.

Hilsch, P., I99I: "Di tutsch kronik von Behem lant. Der Verfasser der Dalimilübertragung und die deutschböhmische Identität", in Kl. Herbers, H. Henning Kortüm, C. Servatius (eds), Ex ipsis rerum documentis. Beiträge zur Mediävistik. Festschrift für H. Zimmermann zum 65. Geburtstag, Sigmaringen, pp. 103II5. 
Hledíková, Z., I99I: Biskup Jan IV. Dražic (I30I-I343), Praha.

Ineichen, G., Schindler, A., Bodmer, D. (red.), 1964: Geschichte der Textüberlieferung der antiken und mittelaterlichen Literatur, II. Textüberlieferung der mittelalterlichen Literatur, Zürich.

JK, 1985: "Alexandreida", in Lexikon české literatury. Osobnosti, díla, instituce (red. V. Forst), I, Praha, pp. 52-53

Johanek, P., I99I: "Hofhistoriograph und Stadtchronist", in Autorentypen (hrsg. von W. Haug u. B. Wachingen), Tübingen, pp. 50-68.

Kašpar, J.,I980: "Staré letopisy české (Přehled dosavadních výzkumů)", in $Z e$ Starých letopisu českých (ed. J. Porák, J. Kašpar), Praha, pp. 453-467

Knihopis, 1925: Knihopis československých tisků od doby nejstarš́ až do konce XVIII. století. Díl I. Prvotisk (do r. I50o), Text. Praha.

Kopecký, M., 1962: Literárni dílo Mikuláše Konáče z Hodiškova, Praha.

Kovár, D., 2007: Tragedie Ondřeje Puklice. Budějovický purkmistr a jeho zavražděni 25. května I467, České Budějovice

Kubín, P., 20II: "Sedm přemyslovských kultü“, Opera Facultatis theologiae catholicae Universitatis Carolinae Pragensis. Historia et historia atrium, I2, Praha .

Kyas, V., I970: "Stáří dvou staročeských překladů Životopisu Karla IV“, Listy filologické, 93, pp. 27I-275.

—-, I981a: "Úvod", in V. Kyas, (ed.), Staročeská bible drážd’anská a olomoucká. Kritické vydání nejstaršiho českého prèeladu bible ze I4. století, I, Praha, pp. II-33.

— , 198Ib: "Vznik staročeského biblického překladu", in Doba Karla IV. $v$ dèjinách národì ČSSR. Mezinárodni védecká konference porádaná Univerzitou Karlovou v Praze k 60o. výroči úmrtí Karla IV. Materiály ze sekce jazyka a literatury, Praha, pp. 48-54.

—- I997: Česká bible v dějinách národního pisemnictví, Praha.

Lamboglia, R., 20Io: "Piccolomini, Eneas Sylvius. (Pope Pius II)“, in G. Dunphy (ed.), Encyclopedia of the Medieval Chronicle, Leiden-Boston, pp.I2I4-I2I5.

Langosch, K., 1990: Mittellatein und Europa. Führung in die Hauptliteratur des Mittelalters, Darmstadt.

Lehír, J., 1983: Nejstarši česká epika. Dalimilova kronika, Alexandreida, pruní veršované legendy, Praha.

Lehár, J., Stich, A., Janáčková, J., Holý, J. (ed.), 2008: Česká literatura od počátki $k$ dnešku, Praha.

Loserth, J., I880/8I: "Historische Aufzeichnungen aus der Hussitenzeit des Stadtschreibers Wenzel von Iglau", Mitteilungen des Vereins für die Geschichte der Deutschen und Böhmen, 19, pp. 8I-89. 
Masařík, Z., I99I: "Zur Sprache der mittelhochdeutschen Dalimilchronik, Brünner Beiträge zur Germanistik und Nordistik“, Sbornik praci filozofické fakulty brnènské univerzity $K, \mathrm{I} 2, \mathrm{pp} .5 \mathrm{I}-64$.

Matthews, A., 20I0: "Twinger, Jakob, von Königshofen“, in G. Dunphy (ed.), Encyclopedia of the Medieval Chronicle, Leiden-Boston, pp. I456-I457.

MM, 20I2: "Pehemische Cronica dewcz", in W. Aschnitz (ed.), Deutsches LiteraturLexikon. Das Mittelalter. Autoren und Werke nach Themenkreisen und Gattungen, Band 3: Reiseberichte und Geschichtsdichtung, Berlin-Boston, pp. 365-306. Molnár, A.(ed.), 1980: Husitské manifesty, Praha.

Nechutová, J., 2007: Die lateinische Literatur des Mittelalters in Böhmen, KölnWeimar-Wien.

Nejedlý, M., I997: "Deux poètes français du quatorzième siècle en Bohême. Rencontres et confrontations", Prague Papers on History of International Relations, Ústav světových dějin, pp. 30-53.

Pražák, E., 1986: "Dalimil Jetřich Berúnský", Česká literatura, 34, pp. 408-413.

Proksch, C., I994: Klosterreform und Geschichtsschreibung im Spätmittelalter, Köln- Weimar-Wien.

Rady, M., 20I2: "The German Settlement in Central and Eastern Europe during the High Middle Ages", in N. Berentd, (ed.), The Expansion of Central Europe in the Middle Ages, Ashgate, pp. 177-2I4.

Reitinger, L., 2015: "Psal tzv. Kanovnik vyšehradský opravdu na Vyšehradě? První Kosmův pokračovatel v kontextu dějepisectvi premyslovského věku“, Český časopis historický, II3, pp. 635-668.

Sedláček, A., I889: Hrady, zámky a turze Království českého, vol. 6, Praha.

—., 1905: Hrady, zámky a tvrze Království českého, vol.ı3, Praha.

—_, 1924: Hrady, zámky a tvrze Království českého, vol. I4, Praha.

Sherwood-Smith, M., 2oro: "Peter Comestor", in G. Dunphy (ed.), Encyclopedia of the Medieval Chronicle, Leiden-Boston, pp. I200-I20I.

Schmale, Fr-J., 1985: Funktion und Formen mittelalterlicher Geschichtsschreibung. Eine Einführung. Mit einem Beitrag v. H.-W. Goetz, Darmstadt.

Schneider, K., .I991: Die deutschen Handschriften der Bayerischen Staatsbibliothek München: Die mittelalterlichen Handschriften aus Cgm 888-4000. (Editio altera), Wiesbaden.

Spunar, P., 1972: "Středověké národní literatury" in Kultura středověku. Několik pohledũ do středověké kultury, Praha, pp. I6I-I80.

Šmahel, Fr., 1988a: "Enea Silvio Piccolomini a jeho Historie česká", in Aeneae Silvii Historia Bohemica (ed. D. Martinková, A. Hadravová, J. Mátl, Fr. Šmahel), Praha, pp. XIII-LII. 
- I988b: "Enea Silvio Piccolomini and His Historia Bohemica", in Aeneae Silvii Historia Bohemica (ed. D. Martinková, A. Hadravová, J. Mátl, Fr. Šmahel), Praha, pp. LIII-XCVII.

—, 2002: Die hussitische Revolution, übersetzt von Thomas Krzenck (red. A. Patschovsky), Hannover.

Šủla, J., I975: "Staré letopisy české XV. století a jejich královéhradecká větev“, Sbornik Národního muzea, rada C, 20, pp. 27-46.

Šủa, J., I979: Kronika velmi pěkná o Janovi Žižkovi, čeledinu krále Václava, Hradec Králové.

Šusta, J.,1939: České dějiny II,2. Král cizinec, Praha.

Šváb, M., I978: "Uplatnění antických témat v českých veršovaných skladbách I3. a I4. století", in Antika a česká kultura (red. L. Varcl), Praha, pp. 5I-66.

Thompson, J. W., 2012: "Medieval German Expansion in Bohemia and Poland (selected excerpts)", in N. Berendt, (ed.), The Expansion of Central Europe in the Middle Ages, Ashgate, pp. I-38.

Tomsa, A., I915: "Rýmovaný německý překlad t. zv. kroniky Dalimilovy a poměr jeho k české předloze“, Časopis pro moderni filologii, 4, pp. 35-48.

Třeštík, D., I968: Kosmova kronika. Studie k počátkưm českého dějepisectví a politického myšlení, Praha.

Tyson, D., 1979: "The Patronage of French Vernacular History Writers in the Twelfth and Thirteenth Centuries", Romania, IOO, pp. I80-222.

Uhlír, Z., 2005: "Nově objevený zlomek latinského prrekladu Kroniky tak řčeného Dalimila“, Knihovna, I6, pp. I37-I64.

— , 2008: "Prokop písař: úředník nebo intelektuál?", in O. Fejtová, V. Ledvinka, J. Pešek (eds.), Město a intelektuálové od středověku do roku I848, Praha, pp. 69-78.

Urbánek, R., 1953: "Satirická skládání Budyšínského rukopisu M. Vavřince z Březové z r. 1420 v rámci ostatní jeho činnosti literární", Vèstník Královské české společnosti nauk, III, pp.I-38.

Vaculinova, M., Brodsky, P., Spurna, K. (eds), 2016: Liber viaticus Jana ze Středy. Komentárový svazek ke zmenšené reprodukci rukopisu XIII A I2 Knihovny Národního muzea $v$ Praze, Praha [forthcoming].

Vašica, J., 200I: Eseje a studie ze starši české literatury, Opava.

Vidmanová, A., 2006: "Nad pař́žskými zlomky latinského Dalimila", Slovo a smysl. Časopis pro mezioborová bohemistická studia, 3/5, , pp. 25-67.

Vraštil, J., I926: "České překlady biblické", in Český slovník bohovédný (red. A. Podlaha), III, Cyrillo-Methodějská knihtiskárna a nakladatelství V. Kotrba, Praha, pp. 334sq. 
Wellendorf, J., 20II: Whetting the Appetite for a Vernacular Literature: The Icelandic Hungrvala, in: Historical Narratives and Christian Identity on a European Periphery. Early History writing in Northern, East-Central and Eastern Europe (c. I070-I200) (ed. by I. H. Garipzanov), Turnhout, pp. III-I42.

Weller, T., 2004: Die Heiratspolitik des deutschen Hochadels iim I2. Jahrhundert, Köln-Weimar-Wien.

Wolverton, L., 2012: Germans and Slavs in I3th-Century Bohemia: Some preliminary remarks on immigrants and law, in N. Berendt (ed.), The Expansion of Central Europe in the Middle Ages, Ashgate, pp. 297-304.

—, 2015: Cosmas of Prague. Narrative, Classicism, Politics, Washington.

ZDT, i993: Lexikon české literatury. Osobnosti, dila, instituce, 2/II, K-L, Praha, pp. 695-697

Zilynskyj, B., 1983: "Novoměstské letopisné záznamy z počátků vlády Ferdinanda I“, Folia historica Bohemica, 5, pp. I5I-I7I.

__ I984: "Letopis měštana Nového Města pražského z let I492.I539“, Pražský sbornik historický, 17 , pp. 52-89.

Zouhar, J., 2007: "Im Schatten der deutschen Reimübertragung der DalimilChronik- Versannalen (der so genannte "Abriss" aus dem I4. Jahrhundert). (Ein Beitrag zur mittelalterlichen deutschsprachigen Literatur in Böhmen“, Listy filologické, I30, I-2, pp. 2I-42.

Žemlička, J., I986: Století posledních Premyslovcu (Český stát a společnost a ve I3. století), Praha.

—_, 2002: Poćátky Čech královských II98-I253, Promèna státu a společnosti, Praha.

—_, 2009: "Rozmach a vrchol přemyslovské moci", in P. Sommer, D. Třeštík, J. Žemlička (eds.), Premyslovci. Budováni českého státu, Praha, pp. 295-317.

- 2012: The Germans and the Implantation of German Law among the Bohemians and Moravians in the Middle Ages, in N. Berendt (ed.), The Expansion of Central Europe in the Middle Ages, Ashgate, pp. 237-270. 